\title{
EDITORIAL
}

\section{New Age International Taxation in the Digital Economy of the Global Society}

\author{
Professor Luc Hinnekens, University of Antwerp
}

We call it 'New Age taxation', but find it difficult to define the meaning of the expression. We hear about New Age civics, New Age political culture, New Age art, New Age technology and even New Age religious beliefs. But no dictionary describes the essence of this common quality. Nor do we find the expression and its specific meaning for tax purposes in any international tax glossary, assuming the term has ever been coined.

New Age taxation does not happen to be new, and it is not just any tax change or tax reform. It very deeply needs and wants to be new because traditional principles and systems of taxation no longer adequately perform their role. New Age taxation is not trendy and is even less faddish. It is fundamentally innovative and marks the transition from twentieth- to twenty-first-century taxation or, in an even longer perspective, from second- to third-millennium taxation. It carries with it a vision of a new age and a new space.

New Age taxation is new because it is realistic. And because new realities are so different, its novelty is also revolutionary. In a sense, the New Age drive is biblical: men do not put new wine into old bottles. Traditional wisdom has it that 'good taxes are old taxes'. Because they are traditional and settled, they promise legal certainty and predictability to the taxpaying citizen and satisfy the politician and the economist as they find their way to their final resting place in the anonymous economy and society via the dark laws concerning shifting of burdens. But this traditional wisdom no longer makes sense when, on the threshold of the twenty-first century, the traditional tax rule is called to apply to fundamentally different situations.

New Age taxation is pervasive and massive. It changes direct taxes as well as indirect taxes, tax thinking as well as tax practice, tax principles as well as tax rules, substantive tax law provisions as well as tax procedures, tax policies as well as tax legislation, administration and jurisprudence.

We like to analyze tax-lawmaking (the 'genesis') as a top-down process: the tax theory (the 'idea') is transformed into tax laws (the 'word') which are accordingly applied to the situation for which they are destined (the 'fiscal fact'). This process is not direct or automatic. In the first place, tax laws are imposed by government and also reflect the programmes of political parties, electorate, lobbying and the entire existing institution. In the second place, their conversion (or non-conversion) into the intended fiscal fact, or in another fiscal situation, is the work of the planning taxpayer.

This top-down model produces traditional tax rules, which are as fixed, established and official as their principles and institutions. But the taxation process also works from the bottom up. As economic realities change, they challenge existing tax rules. As the New Age winds of change are revolutionary and erode old foundations, they also challenge the fundamental tax principles and the established institutions, sovereign as those institutions may be. Their forces are co-determinative for the tax laws, policies and principles, which also become - or should become 'their' new laws, policies, principles and institutions as they respond to their challenges.

New Age taxation is essentially international. Futurologists, sociologists, economists, political scientists, digital experts, philosophers, and gurus preferably combining all those professional skills, tell us that the new realities involve a transformation and globalization of society and of its economy. It is McLuhan's global village: 'Time has ceased, space has vanished. We now live in a simultaneous happening.' The revolution of information and communication technology is very much at the heart of it. 'Being digital' (according to Negroponte's expression) greatly accelerates the international mobility of economic operators and the worldwide integration of their markets. The mobility of the tax base is greater for production than for consumption, and is greater for some factors (capital, software, marketing, manufacturing and communication technology, financial and professional services, energy) than for others (real property, real activities and employed labour). But the affected tax bases cover virtually the entire economy. Also enterprises become increasingly territory-elastic: according to business surveys carried out by the Ruding Committee, ${ }^{1}$ taxation 
is a major factor in locating financial centres (70 per cent of respondents), coordination centres (57 per cent of respondents), and R\&D centres (41 per cent of respondents). Even for production plants, location loses its territory-specificity (48 per cent of respondents). When combined with the future's technology, mobile, immaterialized, global and new tax bases are the new fiscal facts and become, by the same token, the challenges in our New Age bottom-up taxation model.

What, then, are the possibilities and solutions for the makers of the tax laws, the tax policies and the tax treaties, confronted with these challenges?

(i) A first and easy course of action is: do not do anything ('surtout n'y touchez pas!').

But that path is the continuation and even acceleration of the present trend of fiscal degradation. According to EC Member States' revenue statistics during the period 1980-1994, the average EC total tax and social security levels stagnated (i.e. increased by no more than 5 per cent as a percentage of GDP during the 15 years) notwithstanding pressing social security and government revenue needs. The tax burden on capital, self-employed labour and energy (with their implicit tax rate dropping steadily from 44.1 per cent to 35.2 per cent) is progressively shifted to employed labour (with its implicit tax rate increasing from 34.7 per cent to 40.5 per cent). This alteration in the structure of taxation by overcharging labour is contrary to employment policies and interpersonal equity.

The new digital technology helps the interpenetration of the markets, the mobility of capital and enterprise, and the dematerialization of the (financial and professional) services. It also widens the scope of international tax planning and tax avoidance. The process also breeds the tax competitiveness of individual States on those international markets. But fiscal competition to the detriment of other countries and beggar-thy-neighbour tax policies are hardly the answer. The State's tax base becomes even further eroded ('race to the bottom'). If power to tax is power to govern, then fiscal degradation is loss of State sovereignty. The European Commission describes the process as 'an unconscious surrender of sovereignty by each State to market forces in a field that should remain the prerogative of public policy'.2

(ii) This analysis of the risks and causes of the degradation of the traditional tax system points to the other and better course of action. If the fiscal facts have become transnational, then the tax laws and institutions must also become international or operate internationally.

If the traditional concept of individual States' tax sovereignty has become an ineffective exercise in the new context, the time has come for a less imperious and more internationally responsible and accommodating concept of tax sovereignty. Facing shared New Age challenges, the new concept allows and even begs for the international coordination of national tax rules and policies. The new paradox is, therefore, that a State protects its real tax sovereignty by aligning its tax exercise and policies to those of other States. New Age tax legislation is tax reform, and New Age tax reform is international tax reform recognizing new principles responding to the challenges of the forces of the international market and digitization. Monti Report: 'Commission initiatives will be directed at (...) the taxation of international services and the impact of new technologies'.

States might for that same purpose even transfer some of their own tax rights to a central structure responsible for central tax coordination or harmonization. Are individual States prepared for such tax coordination and economic grouping? In the first instance, are EC Member States prepared for it? Time will tell what answer their newly created Taxation Policy Group will give to the call of Commissioner Monti's Report of 22 October $1996 .^{3}$

(iii) Whatever course of action is followed, it must deal with new global taxation principles.

The diagnosis of ongoing fiscal degradation may be easy but the New Age taxation cure is not. It is easy to see that traditional rules of international taxation will no longer do it. It is difficult to identify and impose responsive New Age rules but also New Age principles, as New Age taxation involves not only the rules but the fundamental principles themselves of international taxation. The question is: is fiscal doctrine ready? 'In the disarray of this "fin de siècle", tax policy-makers turn for guidance to the tax theorists, but find that little thought has been given to the shape and form of a comprehensive tax system that is up to the challenge of the new regional (European) and global scene.' 4

An editorial can at best illustrate the fundamental and pervasive nature of the task by raising some of its main issues. They are situated respectively in the very basic areas of the Rule of Law, effectiveness of territoriality, fairness, system-coherence, and alternative tax formulae.

One principle is very traditional (going back to the Magna Carta, the Bill of Rights, the French Revolution, and Western democracy) and almost sacred (often inscribed in a nation's Constitution) in taxation: it is the Rule of Law in the 'Rechtsstaat'. It recognizes the basic tax freedom of every citizen, unless otherwise provided in a tax law which must provide the essential features of his tax liability. The principle is interpreted

\section{Notes}

2 European Commission, 'Taxation in the European Union', 20 March 1996.

3 European Commission, 'Taxation in the European Union, Report on the Development of Tax Systems', 22 October 1996; L. Hinnekens, 'The Monti Report: The uphill task of harmonizing direct tax systems of EC Member States', EC Tax Review 1997/1, p. 31.

4 L. Hinnekens, 'Territoriality-based Taxation in an Increasingly Common Market and Globalizing Economy: Nightmare and Challenge of International Taxation in the New Age', EC Tax Review 1993/3, p. 156. Well before this in 1961 the International Chamber of Commerce had concluded that 'the world cannot wait for the slow evolution of fiscal doctrine'. 
to provide for further principles concerning (detailed) statutory drafting and (strict) interpretation of tax laws (no 'fraus legis' doctrine, 'wirtschaftliche Betrachtungsweise', etc.) and special rules of burden of proof (in dubio contra fiscum).

Can and will these principles maintain their traditional significance in dealing with the highly complex, changeable and international fiscal facts of New Age taxation? A new balance may have to be struck among the technical canons of taxation stressing the need in the digital global economy for effectiveness and simplicity and negotiated solution, even at the cost of legal detail and certainty. John Avery Jones says that "What we need is less detailed legislation construed in accordance with principles, not a continuation of the plague of tax rule madness.' But he is well aware of the untraditional nature of his proposal: 'One might think that, however beneficial it would be if we had less detailed legislation which we interpreted in accordance with principles, this could not happen without a revolution affecting the legislature, the courts, the Revenue Departments and tax advisers that is to say our entire legal culture.'

The second principle is just as fundamental and traditional: the territorial limitation of a State's jurisdiction to tax. Even for those who would not recognize the prohibition of extraterritorial taxation as a principle of general international public law, it is still the best basis of international taxation. Today's internation allocation of tax jurisdiction determines territorial attachment and attribution of income according to traditional tests of accrued benefit and economic allegiance. They date back to the concept of 'wirtschaftliche Zugehörigkeit'. ${ }^{6}$

But how to apply it in cyberspace? Paraphrasing David Edwards, it seems, if not absurd, at least farfetched to discuss and measure an individual State's jurisdiction to tax in terms of shots fired across frontiers, or of negligence of the officer-of-the-watch of S.S. Lotus, where jurisdiction to tax deals with the taxation of coordination or financial and other service and strategic centres operating in the internal market of their globally or regionally integrated MNE business rather than in the external or open market. They thus operate on an elusive territorial basis as far as their location and productivity is concerned in the closely integrated world of MNEs whose turnover exceeds the GNP of most States. It seems likewise far-fetched to try to tax global trading and Internet sales and electronic commerce according to territory-specific standards.

Does the earth still revolve around the sun, where jurisdiction to tax officially depends on territorial benefit and economic allegiance, whereas in the real world national taxation and fiscal competition are themselves the major factors in locating or moving economic operators on the international markets or in cyberspace? Must we re-source traditional 'sources' of international income? Redefine 'permanent establishment' into an attachment that is less than permanent and less of a brick-and-mortar establishment? Must we replace the 'arm's-length' rule by unitary taxation where comparables are increasingly missing? That would be the end of many traditional fiscal principles (fiscal myths?) for which the tax doctrine does not, to date, furnish valid alternatives.

Personal taxation became modern at the end of the last century, when it was levied at progressive rates applied to the taxpayer's global net income. The reasoning was that only his comprehensive income expresses a resident's ability to pay. At the end of the twentieth century, Scandinavian and other European countries acclaim a dual income taxation system as the new alternative to progressive income taxation. The latter formula breaks down in efficiency, and therefore also in real interpersonal fairness, as it does not allow for the effective taxation of income from capital. The capital base has become too mobile. Will the next century return to schedular taxation (considered anachronistic in the mid-twentieth century) when not only capital but also other bases (other than labour) become mobile or dematerialized in the digital economy?

The current system of taxation allows for the deduction of financing charges from business income in exchange for taxation of the recipient of the interest income. How coherent and viable is that system in the new reality, where interest income is not easily or normally taxed (low schedular rate?) in the country of residence (tax haven? black market?) of the recipient (non-profit organization?)? How good and realistic is it, in view of fiscal competition on the financial markets, to assume that high withholding tax will make up for the built-in revenue loss of the system? How realistic is the alternative of the comprehensive business income tax which would disallow any deduction of interest in the same manner as dividends?

Over the years, income taxes and social security charges have grown into the main source of government revenue: more than 70 per cent in several European countries. But the mobility of most economic operators and fiscal competition on the international markets are now eroding this traditional tax base as it moves into the next century.

The OECD and the European Commission looked into VAT as the more steady source. McLure calls it 'the revenue workhorse throughout the world'. But the shift of taxation to VAT will also increase the mobility of this base, starting with the taxable location (so to speak) of information and telecommunication services and electronic commerce.

What about carving out from general VAT those Internet sales and those services, and taxing their

\section{Notes}

5 J. Avery Jones, 'Tax Law: Rules or Principles?', Fiscal Studies 1996, vol. 17, no. 3, p. 89.

6 von Schanz, Zur Frage der Steuerpflicht (1892). 
providers or users according to modulated terms and at rather high rates? They offer an important potential of new wealth and taxpaying capacity. After all, the car road tax was also introduced in Belgium in 1913 as a harmless, minor presumptive income tax, before it was realized that many other taxes could be levied on this new base without exhausting its productivity.

Are energy taxes needed both for government revenue and environmental protection? New Age will deal with the tax problems and revenue promises not only of the world of bits but also of that of global warming, greenhouse gases and energy-saving technology. Today their EC average represents less than 3 per cent of GDP. At least one OECD expert has expressed the greatest expectations in a retrospective view: 'The leaders, writers and opinion formers, economists being eminent among them, anticipated if not the end of taxation as it was currently known, then a modification of the tax base of sufficient size to count as the biggest change in the tax structures since the introduction of the value-added tax. ${ }^{7}$

Maybe we should proclaim this 'fin de siècle', and in particular 1996, the tax year of the awareness of the challenges of a new era to traditional tax principles. 'Just as Teddy Roosevelt used his bully pulpit to lead the country through a perilous transformation from agrarian to industrial society, so Clinton would use his to lead America from the industrial to the information age. ${ }^{8}$ But the building of a bridge to New Age taxation also needs new tax ideas responsive to the challenges of the digital economy. At its Geneva Congress 1996, the International Fiscal Association organized a Jubilee Symposium entitled 'Visions of the Tax Systems of the XX Century', and created a research project on the challenges posed by the revolution in information and communication technology to traditional concepts, rules and principles of international taxation. It should involve the work of such groups as the Organization for Economic Cooperation and Development. Later that same year the US Treasury Department issued its Discussion Paper on Selected Tax Policy Implications of Global Electronic Commerce, eliciting the views of interested taxpayers, practitioners, academics and others (who may submit their comments via e-mail to TAXPOLICY@treas.sprint.com). Still more governments now undertake studies of the tax issues likely to arise in the World Wide Web.

The important thing is the thinking. It should be clear to every student of taxation, especially of income taxation, that the revolutionary realities of the information age and global society create worldwide challenges, in our bottom-up model, to traditional rules and principles of taxation. As tax authorities, tax academics and practitioners, public and private tax organizations become aware of them, they should work together on the New Age answers, lest our Ministers of Finance find themselves as Alice in the Wonderland of cyberspace, virtual companies, virtual territoriality, 24-hour global trading, electronic commerce, financial derivatives, telecommunication-driven special service centres, etc.

Today is question time. How new should New Age taxation be? Can traditional tax concepts and rules continue to be applied to electronic as to conventional commerce by stretching slightly their application? Should new rules of income classification and territoriality be developed for purposes of determining source and allocation of income in the world of global trading and global services? Or should one give up the ghost of a century-old tax tradition and look for new forms of income taxation or replace it by VAT at higher rates or by a new excise ('bit') tax on electronic commerce? On an individual state or EC-harmonized basis?

Some years ago I wrote a book on New Age international taxation ${ }^{9}$ and dedicated it to my university students 'because they would see it happen or not happen in the new age and space'. But changes occur so rapidly, and the new age and space are coming so fast, that I may also be lucky enough to witness how well or how badly the taxation policies of States and economic groupings respond to the New Age challenges. And how good or erroneous my thoughts were.

\section{Notes}

7 M. Pearson, 'The Political Economy of Implementing Environmental Taxes', International Tax and Public Finance, vol. 2, August 1995, $357-373$.

8 Time Magazine, 'No Guts no Glory', 20 January 1997, p. 35.

9 L. Hinnekens, De territorialiteit van de inkomensbelasting op nieuwe wegan en grondslagen (Kluwer Rechtswetenschappen België, 1993). 